\title{
CYTOGENETIC STUDIES IN AVENA, XVI. CHLOROPHYLL FORMATION IN ALBINO SAND OATS UNDER CERTAIN CULTURE CONDITIONS")
}

\author{
ICHIZO NISHIYAMA ${ }^{2)}$ AND FUSAO MOTOYOSHI ${ }^{3)}$ \\ Laboratory of Genetics, Faculty of Agriculture Kyoto University, Kyoto
}

Received April 20, 1966

In recent years, electron microscopical observations (von Wettstein 1958, Maruyama 1961, Eriksson et al. 1961, and others) have suggested that chlorophyll mutations including albinos are generally induced by genetical blocks along the chain of chloroplast development. Besides, from the point of physiological genetics, phenotypic changes of mutants have been studied under culture in synthetic media (Langridge 1955, 1958a, 1958b, Rédei 1960, 1962, Nishiyama and Motoyoshi 1962, Walles 1963).

In a previous study, the authors were successfull in the artificial culture of albino sand oats with panicles appearing around 45-60 days after planting (Nishiyama and Motoyoshi 1962). Some albinos of certain strains colored slightly pale green under certain culture conditions. For the purpose of investigating the environmental factors which are required for the chlorophyll formation in the albino plants, albinos of a strain, KU No. 1246, have been grown in several culture media under different temperatures. The results will be briefly reported in this paper.

\section{MATERIALS AND METHODS}

The albino strain, KU No. 1246, used in this study was obtained in a progeny of trisomics from a triploid hybrid between Avena barbata $(2 \mathrm{n}=28)$ and $A$. strigosa $(2 \mathrm{n}=$ 14). The albinism is due to a single gene mutation although the heterozygotes segregate greens and albinos in a $1: 1$ ratio. All of the greens are heterozygous and no homozygous greens are found (Nishiyama 1934, 1957). The albino seedlings are white, lacking chlorophylls and probably carotenoids, and die in a couple of weeks under the usual sand culture condition.

White's mineral solution, containing powdered agar as described previously (Nishiyama and Motoyoshi, 1962) was used as a basal culture medium. Other substances were added to the basal medium in accordance with experimental purposes.

The culture method of plants was almost the same as mentioned in the previous paper, except for a few modifications. For sterilization of seeds, they were soaked in

1) Contribution from the Laboratory of Genetics, Faculty of Agriculture, Kyoto University, Kyoto, Japan. No. 320.

2) Present address: Dept. of Agronomy, Univ. of Wisconsin, Madison, Wis., U. S. A.

3) Present address: Institute for Plant Virus Research, Aoba-cho, Chiba, Japan 
$80 \%$ ethanol for one minute, washed several times with tap water, soaked in $5 \%$ calcium hypochlorite solution for one hour and washed several times with sterilized water. Two or three seeds were aseptically sown on the basal medium in each test tube. Seeds began to germinate in three days at $20^{\circ} \mathrm{C}$ under weak illumination from day-light fluorescent lamps. Germinating seeds were removed with a metal loop and placed on culture media in other test tubes. Prior to transfer, test tubes with microbial contamination were discarded so that the experimental media were usually free from fungal or bacterial contamination. Besides, this procedure enabled us to obtain uniform seedlings of greens and albinos in the number wanted.

Then the germinants were grown under continuous 1000-1300 lux illumination from day-light fluorescent lamps until the chlorophyll formation and leaf growth were examined.

Spectrometric measurements of chlorophylls a and b were carried out with the first leaves on 12 days after transplantation. For extracting chlorophyll the leaf blades removed from their sheaths were cut into small pieces, soaked in $80^{\circ} \mathrm{C}$ water for 3 minutes and ground in a mortar with $80 \%$ acetone. Then the solution was filtered through filter paper after which chlorophyll was extracted by repeated grinding of the residue. The absorption was measured by Shimazu's spectrophotometer (Type QB-50). According to Mackinney (1941), specific absorption coefficients in $80 \%$ acetone extract of chlorophyll are as follows : 82.04 and 9.27 at $663 \mathrm{~m} \mu$, and 16.75 and 45.60 at $645 \mathrm{~m} \mu$ for chlorophyll $\mathrm{a}$ and $\mathrm{b}$, respectively. Concentrations of chlorophylls $\mathrm{a}$ and $\mathrm{b}$ were calculated from optical densities and specific absorption coefficients.

\section{RESULTS}

1. Effects of glucose concentration in the culture medium and of temperature on chlorophyll formation in albino and normal plants

The previous observation showed that newly emerged leaves of albino plants of this strain colored slightly pale green when they were grown under certain artificial culture conditions, and that especially sugar might be an important exogeneous factor for greening albino leaves at a higher temperature than $20^{\circ} \mathrm{C}$ (Nishiyama and Motoyoshi 1962). In the present study an attempt was made to determine what might be the effective conditions for the formation of chlorophyll in albinos.

First, chlorophyll formations in both albinos and normals were examined under various conditions of different glucose concentrations $(0,0.2$, and $0.4 \mathrm{M})$ and temperatures (18 and $21^{\circ} \mathrm{C}$ ). The amount of chlorophyll (in $\mathrm{mg}$ per $1 \mathrm{~g}$ of fresh leaves) was measured on 12 days after transplantation. As shown in Table 1, the highest concentration of total chlorophyll ( $a$ and $b$ ) in albino leaves was observed in the culture medium with $0.4 \mathrm{M}$ glucose at $21^{\circ} \mathrm{C}$, but the total amount of chlorophylls was about one-tenth of the lowest value in normal leaves (glucose-lacking medium at $18^{\circ} \mathrm{C}$ ). In albino leaves 
grown in the media without glucose, no trace of chlorophyll was found at $18^{\circ} \mathrm{C}$ but a slight amount was found at $21^{\circ} \mathrm{C}$. Thus, chlorophyll formation in albino leaves depends on high glucose concentrations and high temperatures, especially the high temperature $\left(21^{\circ} \mathrm{C}\right)$ being very effective.

The chlorophyll content in normal leaves was also variable in reponse to glucose concentration and temperature. However, the highest value of total chlorophyll, which was obtained in $0.2 \mathrm{M}$ glucose at $21^{\circ} \mathrm{C}$, was about 1.7 times as large as the lowest which was found in the absence of glucose at $18^{\circ} \mathrm{C}$. No definite increase of chlorophyll was observed along with the increase of glucose concentration in normal leaves.

The ratio of chlorophyll a/b was also variable under different culture conditions in both albino and normal leaves.

Table 1. Chlorophyll formation in the first leaves of albino and normal plants grown on media containing different concentrations of glucose at differrent temperatures

\begin{tabular}{|c|c|c|c|c|c|c|c|}
\hline \multirow{2}{*}{ Phenotype } & \multirow{2}{*}{ Temperature } & \multirow{2}{*}{$\begin{array}{l}\text { Concentration } \\
\text { of glucose } \\
\text { (M) }\end{array}$} & \multirow{2}{*}{$\begin{array}{l}\text { No. of } \\
\text { leaves }\end{array}$} & \multicolumn{3}{|c|}{$\begin{array}{c}\text { Chlorophyll content }(\mathrm{mg}) \text { per } 1 \mathrm{~g} \\
\text { of fresh leaf }\end{array}$} & \multirow{2}{*}{$\begin{array}{c}\text { Ratio of } \\
\text { chlorophyll } \\
\text { a to b } \\
(\mathrm{a} / \mathrm{b})\end{array}$} \\
\hline & & & & $\begin{array}{c}\text { Total } \\
\text { chlorophyll }\end{array}$ & $\begin{array}{l}\text { Chloro- } \\
\text { phyll a }\end{array}$ & $\begin{array}{l}\text { Chioro- } \\
\text { phyll b }\end{array}$ & \\
\hline \multirow[t]{6}{*}{ Albino } & $18^{\circ} \mathrm{C}$ & 0.0 & 20 & 0.000 & 0.000 & 0.000 & - \\
\hline & & 0.2 & 20 & 0.003 & 0.002 & 0.001 & 2 \\
\hline & & 0.4 & 20 & 0.013 & 0.010 & 0.003 & 3 \\
\hline & $21^{\circ} \mathrm{C}$ & 0.0 & 20 & 0.008 & 0.005 & 0.003 & \\
\hline & & 0.2 & 20 & 0.010 & 0.007 & 0.003 & 2 \\
\hline & & 0.4 & & 0.000 & 0.044 & 0.010 & 2.0 \\
\hline \multirow[t]{6}{*}{ Normal } & $18^{\circ} \mathrm{C}$ & 0.0 & 5 & 0.617 & 0.470 & 0.147 & 3.2 \\
\hline & & 0.2 & 5 & 0.848 & 0.645 & 0.203 & 3.2 \\
\hline & & 0.4 & 5 & 0.732 & 0.580 & 0.152 & 3.8 \\
\hline & $21^{\circ} \mathrm{C}$ & 0.0 & 5 & 0.677 & 0.514 & 0.163 & 3.2 \\
\hline & & 0.2 & 5 & 1.026 & 0.759 & 0.267 & 2.8 \\
\hline & & 0.4 & 5 & 0.749 & 0.542 & 0.207 & 2.6 \\
\hline
\end{tabular}

Table 2. Chlorophyll formation in the first leaves of albino and normal plants grown on media containing different concentrations of glucose at $21^{\circ} \mathrm{C}$

\begin{tabular}{|c|c|c|c|c|c|c|c|}
\hline \multirow{2}{*}{ Phenotype } & \multirow{2}{*}{$\begin{array}{l}\text { Concentration } \\
\text { of glucose } \\
\text { (M) }\end{array}$} & \multirow{2}{*}{$\begin{array}{l}\text { No. of } \\
\text { leaves }\end{array}$} & \multirow{2}{*}{$\begin{array}{l}\text { Leaf length* } \\
(\mathrm{cm})\end{array}$} & \multicolumn{3}{|c|}{$\begin{array}{c}\text { Chlorophyll content(mg) per } 1 \mathrm{~g} \\
\text { of fresh leaf }\end{array}$} & \multirow{2}{*}{$\begin{array}{c}\text { Ratio of } \\
\text { chlorophyll } \\
\text { a to b } \\
(\mathrm{a} / \mathrm{b})\end{array}$} \\
\hline & & & & $\begin{array}{c}\text { Total } \\
\text { chlorophyll }\end{array}$ & $\begin{array}{l}\text { Chloro- } \\
\text { phyll a }\end{array}$ & $\begin{array}{l}\text { Chloro- } \\
\text { phyll b }\end{array}$ & \\
\hline \multirow[t]{6}{*}{ Albino } & 0.0 & 44 & $5.9 \pm 0.6$ & 0.000 & 0.000 & 0.000 & - \\
\hline & 0.1 & 40 & $6.1 \pm 0.8$ & 0.000 & 0.000 & 0.000 & - \\
\hline & 0.2 & 41 & $6.0 \pm 0.6$ & 0.002 & 0.001 & 0.001 & 1 \\
\hline & 0.3 & 42 & $5.2 \pm 0.8$ & 0.015 & 0.011 & 0.004 & \\
\hline & 0.4 & 41 & $5.5 \pm 0.7$ & 0.058 & 0.041 & 0.017 & 2.4 \\
\hline & 0.5 & 41 & $4.7 \pm 0.6$ & 0.129 & 0.086 & 0.043 & 2.0 \\
\hline \multirow[t]{6}{*}{ Normal } & 0.0 & 15 & $8.5 \pm 1.0$ & 0.976 & 0.706 & 0.270 & 2.6 \\
\hline & 0.1 & 15 & $9.2 \pm 1.0$ & 1.111 & 0.842 & 0.269 & 3.1 \\
\hline & 0.2 & 15 & $7.9 \pm 0.8$ & 1.058 & 0.791 & 0.267 & 3.0 \\
\hline & 0.3 & 15 & $7.8 \pm 0.9$ & 1.324 & 0.984 & 0.340 & 2.0 \\
\hline & 0.4 & 15 & $6.8 \pm 0.7$ & 1.467 & 1.093 & 0.374 & 2.9 \\
\hline & 0.5 & 15 & $6.2 \pm 0.6$ & 0.773 & 0.598 & 0.175 & 3.4 \\
\hline
\end{tabular}

* Mean and standard deviation 
It is evident that the chlorophyll formation in albino leaves is partially dependent on the glucose concentration in the media. A further culture experiment was carried out using the media containing $0-0.5 \mathrm{M}$ glucose at $21^{\circ} \mathrm{C}$, and similar results were obtained as in the experiment mentioned above (Table 2). In albino leaves, total chlorophyll remarkably increased with an increase of glucose concentration, its amount being 0.129 $\mathrm{mg}$ per $1 \mathrm{~g}$ of fresh leaves in the medium with $0.5 \mathrm{M}$ of glucose.

The ratio of chlorophyll a/b varied from 2.6 to 3.4 in normals within the range of glucose concentrations tested, whereas it was 2.4 or 2.0 in albinos grown in the media with 0.4 or $0.5 \mathrm{M}$ of glucose (Table 2 ).

From the preliminary data mentioned above, it was suggested that an increase of chlorophyll content in albino leaves was closely related to high temperature. This relationship was confirmed by a further experiment in which albino plants were grown on the medium containing $0.4 \mathrm{M}$ glucose under different temperatures $\left(18,21,25\right.$ and $\left.30^{\circ} \mathrm{C}\right)$. The chlorophyll content increased sharply at higher temperatures from 18 to $25^{\circ} \mathrm{C}$ (Table 3). As to the elongation of leaves, no significant differences were found between different temperatures, except at $18^{\circ} \mathrm{C}$. Thus chlorophyll formation in albinos is apparently promoted at higher temperatures.

Table 3. Chlorophyll formation in the first leaves of albino plants grown on the medium containing $0.4 \mathrm{M}$ glucose at different temperatures

\begin{tabular}{|c|c|c|c|c|c|c|}
\hline \multirow{2}{*}{ Temperature } & \multirow{2}{*}{$\begin{array}{l}\text { No. of } \\
\text { leaves }\end{array}$} & \multirow{2}{*}{$\begin{array}{l}\text { Leaf length* } \\
\qquad(\mathrm{cm})\end{array}$} & \multicolumn{3}{|c|}{$\begin{array}{c}\text { Chlorophyll content(mg) per } 1 \mathrm{~g} \text { of } \\
\text { fresh leaf }\end{array}$} & \multirow{2}{*}{$\begin{array}{l}\text { Ratio of } \\
\text { chlorophyll } \\
\text { a to b } \\
(\mathrm{a} / \mathrm{b})\end{array}$} \\
\hline & & & $\begin{array}{c}\text { Total } \\
\text { chlorophyll }\end{array}$ & $\begin{array}{l}\text { Chloro- } \\
\text { phyll a }\end{array}$ & $\begin{array}{l}\text { Chloro- } \\
\text { phyll b }\end{array}$ & \\
\hline $18^{\circ} \mathrm{C}$ & 18 & $3.3 \pm 0.6$ & 0.032 & 0.025 & 0.007 & 3.6 \\
\hline $21^{\circ} \mathrm{C}$ & 18 & $4.4 \pm 0.7$ & 0.119 & 0.084 & 0.035 & 2.4 \\
\hline $25^{\circ} \mathrm{C}$ & 16 & $4.3 \pm 0.5$ & 0.235 & 0.153 & 0.082 & 1.9 \\
\hline $30^{\circ} \mathrm{C}$ & 17 & $4.1 \pm 0.7$ & 0.243 & 0.169 & 0.074 & 2.3 \\
\hline
\end{tabular}

* Mean and standard deviation

\section{Effects of mannitol concentrations on chlorophyll formation in albino plants}

From the experiments stated above it is apparent that the albino mutant requires a high concentration of glucose and a high temperature for the chlorophyll formation in leaves. This fact suggests that the albinos might require a high osmotic pressure given by glucose in culture media to produce chlorophyll. To test this possibility, an experiment was carried out using culture media containing substances which could not be utilized by plants as a source of carbon and energy but being provided with high osmotic pressures.

Potassium sulfate, which was very effective for growing an osmotic mutant of Arabidopsis (Langridge, 1958b), inhibited the growth of the albino sand oats, even in the 
low concentration of $0.05 \mathrm{M}$, so that the chlorophyll content in the leaves was not measurable.

In the media cortaining $0.1 \mathrm{M}$ glucose and different concentrations of mannitol $(0-0.4 \mathrm{M})$, the chlorophyll content in albino leaves clearly increased with increasing concentration of mannitol as shown in Table 4. In this case, an inhibition of leaf elongation was observed at higher concentrations of mannitol. The chlorophyll content per leaf also increased with increasing concentration of mannitol up to $0.3 \mathrm{M}$. Therefore, it seems that the increase of chlorophyll is not strongly affected by the inhibition of leaf growth. However, the amount of chlorophyll produced under a high concentration of mannitol was less than that produced under a high concentration of glucose. These results suggest that exogeneous glucose may play an important. role in chlorophyll formation by increasing the osmotic pressure of the medium besides its role as a source of carbon and energy.

Table 4. Chlorophyll formation in the first leaves of albino plants grown on media containing O. $1 \mathrm{M}$ glucose and different concentrations of mannitol $25^{\circ} \mathrm{C}$

\begin{tabular}{|c|c|c|c|c|c|c|c|c|c|}
\hline \multirow{2}{*}{$\begin{array}{l}\text { Concent- } \\
\text { ration of } \\
\text { mannitol } \\
(\mathrm{M})\end{array}$} & \multirow{2}{*}{$\begin{array}{l}\text { No. of } \\
\text { leaves }\end{array}$} & \multirow{2}{*}{$\begin{array}{l}\text { Leaf- } \\
\text { length* } \\
\text { (cm) }\end{array}$} & \multicolumn{3}{|c|}{$\begin{array}{l}\text { Chlorophyll content(mg) } \\
\text { per } 1 \text { g of fresh leaf }\end{array}$} & \multicolumn{3}{|c|}{$\begin{array}{c}\text { Chlorophyll content in } \\
\mu \mathrm{g} / \text { leaf }\end{array}$} & \multirow{2}{*}{$\begin{array}{c}\text { Ratio of } \\
\text { chlorophyll } \\
\text { a to b } \\
(\mathrm{a} / \mathrm{b})\end{array}$} \\
\hline & & & $\begin{array}{c}\text { Total } \\
\text { chlorophyll }\end{array}$ & $\begin{array}{l}\text { Chloro- } \\
\text { phyll a }\end{array}$ & $\begin{array}{l}\text { Chloro- } \\
\text { phyll b }\end{array}$ & $\begin{array}{l}\text { Total } \\
\text { chlorophyll }\end{array}$ & $\begin{array}{l}\text { Chloro- } \\
\text { phyll a }\end{array}$ & $\begin{array}{l}\text { Chloro- } \\
\text { phyll b }\end{array}$ & \\
\hline 0.0 & 13 & $7.1 \pm 1.2$ & 0.014 & 0.011 & 0.003 & 0.18 & 0.14 & 0.04 & 3.7 \\
\hline 0.1 & 13 & $6.8 \pm 0.7$ & 0.025 & 0.020 & 0.005 & 0.25 & 0.20 & 0.05 & 4.0 \\
\hline 0.2 & 13 & $6.0 \pm 1.0$ & 0.038 & 0.030 & 0.008 & 0.32 & 0.25 & 0.07 & 3.8 \\
\hline 0.3 & 15 & $3.3 \pm 0.6$ & 0.071 & 0.049 & 0.022 & 0.44 & 0.30 & 0.14 & 2.2 \\
\hline 0.4 & 14 & $2.2 \pm 0.8$ & 0.078 & 0.054 & 0.024 & 0.32 & 0.22 & 0.10 & 2.3 \\
\hline
\end{tabular}

* Mean and standard deviation

\section{Effects of amino acids and vitamins on chlorophyll formation in albino plants}

An attempt was made to find out whether some substances other than glucose might be effective in producing chlorophyll in the cultured albino plants. For this purpose, the effects of amino acids and vitamins given to the culture medium were tested.

One mixture of 19 kinds of amino acids and L-asparagine, and another mixture of several vitamins were added together or separately to the basal medium supplemented with $0.4 \mathrm{M}$ mannitol but without glucose. Mannitol was added to the basal medium in order to provide it with a high osmotic pressure. The amino acid-mixture was consisted of L-alanine, L-arginine. $\mathrm{HCl}$, L-aspartic acid, L-glutamic acid, glycine, L-histidine. $\mathrm{HCl} . \mathrm{H}_{2} \mathrm{O}$, L-hydroxyproline, L-isoleucine, L-leucine, L-glycine. $\mathrm{HCl}$, L-methionine, L-phenylalanine, L-proline, L-serine, L-threonine, L-tryptophane, L-tyrosine, L-valine and L-asparagine, each in the amount of $100 \mathrm{mg}$, and $25 \mathrm{mg}$ of cystine. The vitamin-mixture contained $20 \mathrm{mg}$ of L-ascorbic acid, calcium pantothenate, inositol. $2 \mathrm{H}_{2} \mathrm{O}$, nicotinic acid, pyridoxine. $\mathrm{HCl}$, riboflavin and thiamine. $\mathrm{HCl}$, and $2.0 \mathrm{mg}$ of folic acid. Each of these mixtures was added to 1 liter of the $0.4 \mathrm{M}$ mannitol-medium. Five kinds of media were 
used for the test: $\mathrm{M}, 0.4 \mathrm{M}$ mannitol; $\mathrm{M}+\mathrm{V}, 0.4 \mathrm{M}$ mannitol plus vitamin-mixture; $\mathrm{M}+$ A, $0.4 \mathrm{M}$ mannitol plus amino acid-mixture; $\mathrm{M}+\mathrm{V}+\mathrm{A}, 0.4 \mathrm{M}$ mannitol plus vitamin- and amino acid-mixtures; and $\mathrm{G}, 0.4 \mathrm{M}$ glucose.

As can be seen in Table 5, the growth of albinos in these media was not as good as in the glucose-medium, when the leaf lengths were compared. Also, their chlorophyll formation was much reduced. Among the four newly prescribed media, the $\mathrm{M}$ $+\mathrm{V}$ medium was the most adequate for the formation of chlorophyll, and the $\mathrm{M}+\mathrm{A}$ gave the least amount of chlorophyll.

Table 5. Chlorophyll formation in the first leaves of albino plants grown on media containing vitamin- or amino acid-mixture or combination of these mixtures at $25^{\circ} \mathrm{C}$

\begin{tabular}{|c|c|c|c|c|c|c|}
\hline \multirow{2}{*}{ Medium* } & \multirow{2}{*}{$\begin{array}{l}\text { No. of } \\
\text { leaves }\end{array}$} & \multirow{2}{*}{$\begin{array}{l}\text { Leaf length** } \\
(\mathrm{cm})\end{array}$} & \multicolumn{3}{|c|}{$\begin{array}{l}\text { Chlorophyll content(mg) per } 1 \mathrm{~g} \text { of } \\
\text { fresh leaf }\end{array}$} & \multirow{2}{*}{$\begin{array}{c}\text { Ratio of } \\
\text { chlorophyll } \\
\text { a to b } \\
(\mathrm{a} / \mathrm{b})\end{array}$} \\
\hline & & & $\begin{array}{c}\text { Total } \\
\text { chlorophyll }\end{array}$ & $\begin{array}{l}\text { Chloro- } \\
\text { phyll a }\end{array}$ & $\begin{array}{l}\text { Chloro- } \\
\text { phyll b }\end{array}$ & \\
\hline M & 12 & $2.2 \pm 0.4$ & 0.044 & 0.030 & 0.014 & 2.1 \\
\hline$M+V$ & 15 & $1.9 \pm 0.7$ & 0.061 & 0.040 & 0.021 & 1.9 \\
\hline$M+A$ & 19 & $1.7 \pm 0.7$ & 0.029 & 0.022 & 0.007 & 3.1 \\
\hline$M+V+A$ & 13 & $1.9 \pm 0.6$ & 0.038 & 0.023 & 0.015 & 1.5 \\
\hline G & 15 & $3.9 \pm 0.4$ & 0.150 & 0.110 & 0.040 & 2.8 \\
\hline
\end{tabular}

* $\mathrm{M}: 0.4 \mathrm{M}$ mannitol, $\mathrm{M}+\mathrm{V}: 0.4 \mathrm{M}$ mannitol plus vitamin-mixture, $\mathrm{M}+\mathrm{A}: 0.4 \mathrm{M}$ mannitol plus amino acid-mixture, $\mathrm{M}+\mathrm{V}+\mathrm{A}: 0.4 \mathrm{M}$ mannitol plus vitamin-mixture plus amino acid-mixture, $\mathrm{G}: 0.4 \mathrm{M}$ glucose

** Mean and standard deviation

4. Effects of casein hydrolysate, kinetm and indolacetic acid on chlorophyll formation in albino plants

It has been reported that kinetin, known as a substance promoting cell division (Miller et al. 1956) has an activity to prevent degeneration of chlorophylls accumulated in green leaves (Richmond and Lang 1957).

A preliminary observation was made to study the effect of kinetin and indole-3acetic acid (IAA) on chlorophyll formation in albino plants. The complete medium contained kinetin, $10^{-6} \mathrm{M}$; IAA, $2 \times 10^{-5} \mathrm{M}$; casein hydrolysate, $2 \mathrm{~g} / l$; glucose, $0.2 \mathrm{M}$; and basal inorganic chemicals. Each test medium was lacking only one of the organic components mentioned just above in the complete medium.

In this experiment the highest amount of chlorophyll was found in albino plants grown in the complete medium, and the chlorophyll content decreased gradually in order of medium lacking casein hydrolysate, kinetin, IAA, and glucose (Table 6). This result may suggest that these four substances, namely glucose, IAA, kinetin, and casein hydrolysate, promote chlorophyll formation in this order under the culture conditions. Glucose is clearly the most important factor for chlorophyll formation, and its removal from the complete medium resulted in a conspicuous decrease of chlorophyll content in albino leaves. A little decrease of chlorophyll was observed when casein hydrolysate 
had been removed from the complete medium. This fact suggests that glucose can not be replaced by casein hydrolysate for chlorophyll formation in the albino leaves. IAA and kinetin which had been added to the complete medium showed promoting effects, and the former was more effective than the latter.

Table 6. Chlorophyll formation in the first leaves of albino plants grown on media containing various combinations of glucose, casein hydrolysate, indoleacetic acid and kinetin at $25^{\circ} \mathrm{C}$

\begin{tabular}{|c|c|c|c|c|c|c|}
\hline \multirow{2}{*}{ Medium* } & \multirow{2}{*}{$\begin{array}{l}\text { No. of } \\
\text { leaves }\end{array}$} & \multirow{2}{*}{$\begin{array}{l}\text { Leaf length** } \\
\quad(\mathrm{cm})\end{array}$} & \multicolumn{3}{|c|}{$\begin{array}{c}\text { Chlorophyll content(mg) per } 1 \mathrm{~g} \text { of } \\
\text { fresh leaf }\end{array}$} & \multirow{2}{*}{$\begin{array}{c}\text { Ratio of } \\
\text { chlorophyll } \\
\text { a to b } \\
\text { (a/b) }\end{array}$} \\
\hline & & & $\begin{array}{c}\text { Total } \\
\text { chlorophyll }\end{array}$ & $\begin{array}{l}\text { Chloro- } \\
\text { phyll a }\end{array}$ & $\begin{array}{l}\text { Chloro- } \\
\text { phyll b }\end{array}$ & \\
\hline Complete & 10 & $4.7 \pm 0.5$ & 0.053 & 0.043 & 0.010 & 4.3 \\
\hline Complete-CH & 10 & $4.6 \pm 0.3$ & 0.044 & 0.033 & 0.011 & 3.0 \\
\hline Complete-KIN & 10 & $5.0 \pm 0.6$ & 0.033 & 0.025 & 0.008 & 2.1 \\
\hline Complete-IAA & 10 & $5.2 \pm 0.7$ & 0.022 & 0.016 & 0.006 & 2.7 \\
\hline Complete-glucose & 10 & $5.0 \pm 0.5$ & 0.006 & 0.004 & 0.002 & 2.0 \\
\hline
\end{tabular}

* Complete medium contains $2 \mathrm{~g} / 1$ of casein hydrolysate $(\mathrm{CH}), 10^{-6} \mathrm{M}$ of kinetin(KIN), $2 \times 10^{-5} \mathrm{M}$ of indol-3-acetic $\operatorname{acid}(\mathrm{IAA})$ and $0.2 \mathrm{M}$ of glucose.

** Mean and standard deviation

\section{DISCUSSION}

The artificial culture of the albino sand oats has indicated that chlorophyll formation in their leaves varies in response to the concentration of glucose present in the media and to the temperature condition. In general, the higher the concentration of glucose or temperature was, the higher the chlorophyll content of albino leaves was.

In normal plants the chlorophyll content was also variable to some extent under different culture conditions.

Glucose seems to play at least two main roles in chlorophyll formation in albino plants, as a source of carbon or energy and also as a conditioning factor of leaf cells, probably providing culture medium or leaf cells with an adequate osmotic pressure. Langrige $(1958 \mathrm{a}, \mathrm{b})$ reported that a mutant of Arabidopsis required for its growth a high osmotic pressure provided by sugar or potassium sulfate in medium for its growth, but mannitol was quite toxic against its growth. In the albino mutant used in the present study high concentrations of mannitol promote chlorophyll formation, but inhibit leaf growth. Growth promoting effects of sugars on albino plants have been observed by several authors (Spoehr 1942, Langridge 1958a, Sugino 1961, and others). As stated above, the exogeneous glucose is very effective not only for growth but also for chlorophyll formation in the albino sand oats (Nishiyama and Motoyoshi 1962).

Indole-3-acetic acid and kinetin have a slightly stimulating effect on chlorophyll formation although their physiological roles are not yet exactly known. On the other hand, it has been shown that albino plants grew very well and produced panicles when 
an auxin, $\alpha$-naphthaleneacetic acid (NAA) was added to the culture medium (Nishiyama and Motoyoshi, unpublished).

Walles (1963) observed that a certain number of chlorophyll mutants in barley became green when they were grown in media containing certain amino acids, and that the structures of their chloroplasts appeared to be developed in the direction to those in normals. Maruyama (1961) made electron microscopical observations on the morphology of chloroplasts of albinos and other color mutants in sand oats. According to him, the albino plant, which was of the same strain used in this study, had remarkably deformed chloroplasts, showing only a few rudimental lamellae in plastids.

In the present experiment albino plants, grown under best conditions, produced approximately $10 \%$ as much chlorophyll as did normal plants. Since the albino mutant is able to produce chlorophylls when grown on the synthetic media, it might not be blocked along the biosynthetic pathway of chlorophyll. As indicated by Maruyama's observation, the genetic block in the mutant might be involved in the differentiation of chloroplasts.

\section{SUMMARY}

An albino mutant (KU No. 1246) of sand oats was grown in several culture media or under different temperatures, and chlorophyll formation was observed in their leaves.

Higher concentrations of glucose $(0.3-0.5 \mathrm{M})$ in the basal medium resulted in a greater production of chlorophyll when albinos were grown at $21^{\circ} \mathrm{C}$. On the other hand, albinos cultured under higher temperatures $\left(21-30^{\circ} \mathrm{C}\right)$ also produced a larger amount of chlorophyll. However, the chlorophyll content of albino leaves was less than $10 \%$ of that of normal greens grown under the same conditions.

A similar increase of chlorophyll in albino was also observed in the media containing $0.1 \mathrm{M}$ glucose and a high concentration of mannitol $(0.3-0.4 \mathrm{M})$. Thus, it is presumed that a part of the effect of glucose might be of providing the medium with a high osmotic pressure which could be substituted by mannitol.

A vitamin-mixture and indole-3-acetic acid seem to be slightly effective on the chlorophyll formation in the albino plants.

\section{LITERATURE CITED}

Eriksson, G., A. Kahn, B. Walles, and D. von Wettstein, 1961 Zur makromolekular Physiologie der Chloroplasten, III. Ber. Deut. Botan. Ges. 74: 221-232.

Langridge, J., 1955 Biochemical mutations in the crucifer Arabidopsis thaliana (L.) Heynh. Nature 176: $260-261$.

Langridge, J., 1958a A hypothesis of developmental selection exemplified by lethal and semilethal mutant of Arabidopsis. Australian J. Biol. Sci. 11: 58-68.

Langridge, J., 1958b An osmotic mutant of Arabidopsis thaliana. Australian J. Biol. Sci. 11: 457-470. 
Mackinney, G., 1941 Absorption of light by chlorophyll solution. J. Biol. Chem. 140: 315-322.

Maruyama, I., 1961 Electron microscope observation on the development of chloroplasts of Avena and chlorophyll deficient mutants. Cytologia 26: 105-115.

Miller, C. O., F. Skoog, F. S. Okumura, M. G. von Saltza, and F. M. Strong, 1956 Isolation, structure and synthesis of kinetin, a substance promoting cell division. J. Amer. Chem. Soc. 78: 13751380 .

Nishiyama, I., 1934 The genetics and cytology of certain cereals, VI. Chromosome behavior and its bearing on inheritance in triploid Avena hybrids. Mem. Coll. Agr. Kyoto Imp. Univ. 32: 1-157.

Nishiyama, I., 1957 Cytogenetic studies in Avena, VII. Mutation in the progeny of triploid Avena hybrids. Proc. Intern. Genet. Symp. 1956 (Tokyo and Kyoto): 318-320.

Nishiyama, I., and F. Motoyoshi 1962 Cytogenetic studies in Avena, X. The artificial culture of albino sand oats. Japan. J. Genetics 37: 427-440.

Rédei, G., 1960 Genetic control of 2,5-dimethyl-4-aminopyrimidine requirement in Arabidopsis thaliana. Genetics 45: 1007.

Rédei, G., 1962 Genetic block of "vitamine thiazole" synthesis in Arabidopsis. Genetics 47: 979.

Richmond, A.E., and A. Lang 1957 Effect of kinetin on protein content and survival of detached Xanthium leaves. Science 125: 650-651.

Spoehr, H. A., 1942 The culture of albino maize. Plant Physiol. 17: 397-410.

Sugino, M., 1961 Photoperiodic response of an albino mutant of einkorn wheat in aseptic culture. Science 134: 1529-1530.

Walles, B., 1963 Macromolecular physiology of plastids, IV. On amino acid requirement of lethal chloroplast mutants in barley. Hereditas 50: 317-344.

Wettstein, D. von, 1958 The formation of plastid structures. Brookhaven Symp. Biol. 11: 138-159. 